\title{
Africa joins the growth capital revolution: Examining the growth of venture capital in the continent
}

Tom L. Osborn ${ }^{\text {a* }}$

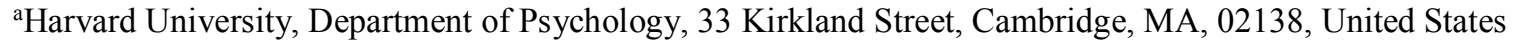

\begin{abstract}
Small businesses play an important role in African economies. But because of a funding gap, many of these businesses struggle to access adequate growth capital. Venture capital (VC) can fill this funding gap and has emerged as an important global source of growth capital. While VC can help grow African businesses, our understanding of VC activities in Africa remains limited. Sparse research has limited the ability of small business owners to expand their financing options. We use a sample of $120 \mathrm{VC}$ funds that primarily invest in Africa to investigate trends in the growth of $\mathrm{VC}$ activities in Africa, as well as to examine the associations between VC fundraising and micro-level firm variables between 2000-2018. We find that at least $\$ 4.57 \mathrm{~b}$ of VC funding has been raised during this period by African VC funds. We observe that most funds keep diversified portfolios and invest in businesses at various stages of growth, and that funds prefer to keep their investment activities within domiciled countries. Using a multiple linear regression model, we find significant associations between VC fundraising and VC fund type, location focus, and vintage year. We do not find any associations between VC fundraising and industry focus, fund manager domicile or fundraising target size. These findings are important because small businesses can better assess their funding options, VC firms can update their strategies, and policy makers can update their policy priorities.
\end{abstract}

Keywords: Venture capital, Africa, small businesses, financial inclusion.

*Corresponding Author, E-mail: tomleeosborn@gmail.com

\section{Introduction}

Venture capital (VC) has emerged as an increasingly global investment tool over the last two decades. The VC industry has expanded from its traditional North American and Western European origins to many of the other regions of the world (Nahata, Hazarika, \& Tandon, 2014). This emergence of VC as a global financing tool is particularly important because VC is an essential source of funding for small and young businesses that often struggle to access traditional capital markets (Gompers \& Lerner, 2001). While Africa has not been left behind by this global expansion of $\mathrm{VC}$, limited research has explored the nature of VC activity in the continent. As such, this paper seeks to advance our existing knowledge of the VC landscape in Africa. Specifically, we seek to: (1) assess and report trends in the growth of $\mathrm{VC}$ activities in Africa, commenting particularly on industry and geographical drivers of the same, and (2) examine a particular VC activity: VC fundraising, and evaluate the associations 
between VC fundraising and micro-level firm variables amongst VC funds with a primary investment focus in Africa between the year 2000 and 2018.

\section{Small business, the 'missing middle' and venture capital}

Small businesses play an important economic role in low-income regions such as Africa. These businesses, often young, drive innovation and create new market opportunities that spur economic growth (Lerner \& Tåg, 2013). This catalytic role of small enterprises is especially important in Africa where small firms are the backbone of the economy. Indeed small businesses contribute significantly to the GDP of a majority of African economies, often accounting for in excess of 55\% of annual GDP (Abor \& Quartey, 2010; Kauffmann, 2005). When compared to the GDP contribution of small businesses in middle - income regions $(30 \%)$ and industrialized regions (12\%), the value of small businesses in Africa cannot be overstated (Ayyagari, Demirgüç-Kunt, \& Beck, 2003). But even though small businesses are essential in driving economic output, many of them struggle to access the financing that they need to grow and scale. This inadequacy of accessible capital is a major detriment to the emergence and growth of innovative young firms in Africa (Kauffmann, 2005).

The financial institutions across Africa often struggle to meet the needs of small innovative businesses, thus limiting their financing options. Let us consider a couple of reasons why entrepreneurial finance options in Africa leave many small businesses behind. First, there has been an extensive focus on microfinance across the continent in the past decades (Gbandi \& Amissah, 2014). Microfinance tends to focus on micro-ventures of a nondisruptive nature run by solo entrepreneurs at the bottom of the pyramid (Baumann, 2004; Lapenu \& Zeller, 2001; Mosley \& Rock, 2004; Woller, 2002). While there is immense value 
to microfinance-microfinance lifts individuals from poverty (de Haan \& Lakwo, 2010; Ksoll, Lilleør, Lønborg, \& Rasmussen, 2016; Miled \& Rejeb, 2015) and has spurred the growth of the informal business sector across Africa sector (Lafourcade, Isern, Mwangi, \& Brown, 2005; Miled \& Rejeb, 2015) — the needs of innovative small firms with the potential to scale far outweigh the capabilities of microfinance institutions. Unfortunately, microfinance institutions cannot write checks large enough for these businesses. Second, traditional financing options (i.e. debt financing, private equity) present significant legal and financing obstacles to many small businesses such that only large firms are able to take advantage of them (Fatoki \& Odeyemi, 2010; Kauffmann, 2005). As such, there is a funding gap for many small businesses. They are apparently too large for microfinance and too small to access traditional financing. This gap in funding is now commonly referred to as the "missing middle" (Phillips \& Bhatia-Panthaki, 2007).

Lerner and Tåg (2013) showed that young businesses generally struggle to raise money from traditional financing systems because of moral hazard (i.e. the entrepreneur is incentivized to spend investor money) and information asymmetry (i.e. investors fear that entrepreneurs only issue equity when their firms are overvalued). But VC firms have an investment model that allows them to overcome these issues. Through a process that involves detailed screening, protective financial contracts, demand for control and provision of advice and business development support to investees, VC firms are able find and fund promising small businesses (see Lerner and Tåg 2013 for more information). Similarly, VC firms deploy patient capital (Gompers \& Lerner, 2001). As they deploy long-term capital, the VC firms are forced to take extra caution when making investment decisions, a characteristic that potentially rewards the most promising and competitive young businesses. Beyond this, patient capital allows the entrepreneurs an opportunity to focus on growing and scaling their 
businesses without the immediate burden of repaying for financing (Sapienza, 1992). It is because of these reasons that VC can potentially fill this "missing middle" funding gap. By providing capital to innovative and high-potential small businesses, VC funding can be a shot in the arm that stimulates overall economic growth (Adongo, 2011).

\section{A tale of two cities: Some trends in VC funding in Africa and around the world}

As VC funding has grown globally over the past two decades, the industry has also undergone drastic changes (Bertoni, Colombo, \& Quas, 2015; Harrison \& Mason, 2019). For instance, VC has evolved from its traditional approach of management by experienced entrepreneurs funding early stage companies, through the rise of angel investors and small checks (under $\$ 1 \mathrm{~m}$ ), to the recent phenomenon of crowdfunding and coin offerings (Harrison and Mason 2019). Regardless, it is clear that VC firms continue to raise and invest significant amounts of money all over the world. In 2018, it has been reported that over \$293 billion was invested in some 34,000 VC deals around the world (Rowley, 2019), more than double the \$120 billion estimated to have been invested in 20001.

While the VC industry has grown in leaps and bounds globally, growth in Africa has been mild when compared to other regions of the world (Memba, Gakure, \& Karanja, 2012). Different explanations have been offered to explain this observation. One of the explanations considers the role of institutions in enabling VC activities (Nahata et al., 2014). It is wellestablished that VC activities require a certain environment to succeed. For example, a business-friendly legal environment that offers protection for $\mathrm{VC}$ investors, provides an effective corporate governance structure, and stipulates favorable bankruptcy and labor-

\footnotetext{
${ }^{1}$ Statistic estimate provided by Statista, an online provider of market and consumer data.
} 
market laws is considered essential for a thriving VC industry (Bruton, Ahlstrom, \& Yeh, 2004; Cumming, 2005; Guler \& Guillén, 2010; Lerner \& Tåg, 2013). Many African countries have struggled to provide such an environment, as evidenced by the generally low rankings of these countries in the World Bank's Ease of Doing Business rankings ${ }^{2}$. Another explanation has been the underdeveloped capital markets in African countries (Jefferis \& Smith, 2005; Kenny \& Moss, 1998; Rwegasira, 2000). VC firms need to make money on their investments, and often capital markets provide these firms with an opportunity to exit (Black \& Gilson, 1998; Gompers \& Lerner, 2001). As such, the underdeveloped capital markets in many African economies offer limited opportunities for VC exits limiting the growth of the same in the continent.

Still, the growth in VC in Africa cannot be overstated. While not as rapid as other regions, $\mathrm{VC}$ is increasing the ways in which many small businesses in the continent access growth capital.

\section{Present study and hypotheses}

The present paper attempts to analyze the trends in the growth of VC funding across Africa from 2000 to 2018. Such an analysis is important for various reasons: 1) small business can profit immensely from considering the drivers of VC funding as such an understanding allows them to assess their financing options, 2) understanding the correlates of VC fundraising can be of profound importance to VC investors and VC funds as they determine and update their strategies, and 3) policy makers keen to attract capital for small businesses can take note of these findings in order to shape their policy priorities.

\footnotetext{
${ }^{2}$ The World Bank's Doing Business project provides objective measures of business regulations for local firms in 190 economies and selected cities at the subnational level.
} 
We begin by looking at the growth of venture capital funding across Africa, commenting on the industry and geographical drivers of the same. We then conduct an analysis of $\mathrm{VC}$ funds to assess associations between micro-level firm variables and total fundraising for VC funds investing in Africa. To achieve this objective, we consider VC funds along various micro dimensions that can allow us to characterize these funds. These dimensions include: 1) VC fund type (whether fund focuses on early stage, expansion or late stage ventures), 2) industry focus (primary industry of investees), 3) location focus (geographical focus of investments as well as location of fund manager), and 4) vintage year (the year in which the first influx of capital is delivered to VC fund). These dimensions have been considered when examining VC industries in other regions (Bertoni et al., 2015).

We limit ourselves to two hypotheses:

Hypothesis 1: Industry focus is associated with VC fundraising

VC funds allocate resources differently across various industries. There are generalist funds that consider many industries and have diversified portfolios. Similarly, there are specialized funds that invest in firms within a specific industry (Gompers, Kovner, \& Lerner, 2009). In Africa, industry focus maybe especially important for VC funds as diverse industries present different challenges and offer varying opportunities. For instance, the expansion of mining infrastructure is going to open up many remote areas in Africa to modern agriculture, potentially increasing production, but the challenge of landgrab due to weak governance can limit investor confidence (Weng et al., 2013). As such, we predict that industry focus will be significantly associated with VC fundraising. 
Hypothesis 2: Geographical focus of VC fund and location of fund manager is associated with VC fundraising

Geography plays an important role in VC (Elango, Fried, Hisrich, \& Polonchek, 1995). VC firms tend to locate themselves and invest in firms that are located in regions that have documented success of VC-backed investments and geographical location influences the performance outcomes of VC funds (Chen, Gompers, Kovner, \& Lerner, 2010). In Africa, various geographical regions have different institutions, regulatory frameworks and business climates. As such, geography plays an important role in determining $\mathrm{VC}$ fundraising in Africa, VC funds located in or focusing on geographical regions that have favorable business and investment climates should raise more funding. As such, we predict that geographical focus will be significantly associated with VC fundraising.

We had no prior hypothesis regarding the influence of fund type or vintage year on the size of VC funds across the continent.

\section{Materials and Methods}

\section{Data: Sourcing and operationalizing of variables}

We sourced data from the Preqin database. The database allows searching for private equity funding. We focused our search on funds whose investment type was 'venture', all subtypes within this category were included. As our focus was on Africa, we limited our search to such

funds that had Africa as a geographical focus. For the purposes of the present study, we also limited the funds by vintage year, restricting the search to funds whose vintage year was 2000 to 2018. We further limited our search to funds which had either been closed or liquidated. No other restriction was imposed on the search. This search returned 172 funds. The search 
results were manually exported as a csv file. As our focus was on Africa, we manually filtered the search results to only include VC funds whose primary geographical focus was the continent. This process left us with 120 funds which formed our sample.

In order to operationalize the variables of interest for this study, we considered some of the micro-level firm variables that the Preqin database provides. For instance, VC fundraising was operationalized as the final fund size provided for each firm by Preqin. In a similar manner, the data on vintage year, fund type, target size, industry focus, location focus, and fund manager domicile allowed us to operationalize the other variables of interest (see Table 1 for a detailed description of study variables).

In cases where data was missing, we conducted a manual search on the internet to determine the data values. In some cases, we reached out via email correspondence to the VC funds with a request for the information. For $2 \%$ of the sample, some data was missing. This missing data were imputed five times using the Fully Conditional Specification (FCS) using multivariate imputation by chained equations (mice) algorithm in $\mathrm{R}$ (see van Buuren and Groothuis-Oudshoorn 2011 for a step-by-step description).

After constructing the above dataset, we used the World Bank's Doing Business database to build a separate dataset of the Ease of Doing Business Rank for the countries in Africa that we identified had VC fund(s) domiciled within their borders.

\section{Data analysis plan}

We began by calculating descriptive sample statistics. We then conducted an exploratory data analysis to identify trends in VC fundraising.

When assessing the associations between VC fundraising and micro-level firm variables (vintage year, fund type, fund target size, industry focus, location focus, and fund manager 
location), we were cognizant that these firm variables were to some degree confounded with each other. Therefore, we controlled for these confounding by adding all the variables as covariates.

We built a multiple linear regression model to assess the association between VC fundraising and the following micro-level firm variables: vintage year, fund manager, fund type, fund target size, industry focus, location focus, and fund manager location. In the model, all the variables were entered concurrently to examine the effects of each with the others controlled for.

\section{Results}

\section{Sample Characteristics}

Table 2 shows time series data of total VC fundraising in each year from 2000 to 2018 . As can be seen, there has been a steady increase in VC fundraising in Africa since 2000 (also see Figure 1). At the start of the decade, only $\$ 29.1 \mathrm{~m}$ was raised for $\mathrm{VC}$ activities in the continent. The number has now steadily risen to $\$ 704.8 \mathrm{~m}$ in 2018 , a $2305 \%$ increase. In that period, a total of $\$ 4,756.80 \mathrm{~m}(\mathrm{M}=\$ 39.40 \mathrm{~m}, \mathrm{SD}=\$ 41.51 \mathrm{~m})$ has been raised by VC funds investing in Africa.

\begin{tabular}{cccccc}
\hline $\begin{array}{c}\text { Vintage } \\
\text { Year }\end{array}$ & $\begin{array}{c}\text { Total } \\
\text { Fund Size }\end{array}$ & $\begin{array}{c}\text { Number of } \\
\text { Funds (N) }\end{array}$ & $\begin{array}{c}\text { Number } \\
\text { of Firms } \\
(\mathrm{N})\end{array}$ & $\begin{array}{c}\text { Average } \\
\text { Fund Size }\end{array}$ & $\begin{array}{c}\text { Fund Size } \\
\text { SD }\end{array}$ \\
\hline 2000 & 29.1 & 2 & 2 & 14.55 & 12.23 \\
2001 & 45.5 & 2 & 2 & 22.75 & 15.32 \\
2002 & 88.88 & 4 & 4 & 22.22 & 23.77 \\
2003 & 207.87 & 7 & 5 & 29.7 & 17.2 \\
2004 & 51.61 & 3 & 3 & 17.2 & 15.14 \\
2005 & 93.49 & 4 & 4 & 23.37 & 12.51 \\
2006 & 195.28 & 7 & 7 & 27.9 & 16.86 \\
2007 & 785.8 & 16 & 15 & 49.11 & 37.85 \\
2008 & 572.22 & 8 & 8 & 71.53 & 51.72 \\
\hline \hline
\end{tabular}




\begin{tabular}{cccccc}
\hline \hline 2009 & 147.13 & 6 & 6 & 24.52 & 28.57 \\
2010 & 154.83 & 8 & 8 & 19.35 & 16.12 \\
2011 & 309.83 & 8 & 8 & 38.73 & 40.76 \\
2012 & 159.21 & 7 & 7 & 22.74 & 24.92 \\
2013 & 124.38 & 6 & 6 & 20.73 & 30.06 \\
2014 & 185.8 & 4 & 4 & 46.45 & 41.52 \\
2015 & 164.29 & 6 & 6 & 27.38 & 23.41 \\
2016 & 563.79 & 8 & 8 & 70.47 & 84.6 \\
2017 & 205 & 3 & 3 & 68.33 & 54.85 \\
2018 & 704.86 & 11 & 10 & 64.08 & 49.84 \\
\hline \hline
\end{tabular}

Table 2. Time series data showing VC fundraising in Africa from 2000 to 2018. Other relevant information such as numbers of funds, number of firms (fund managers), and average fund size (average of total fundraising) are also highlighted.

Regarding the fund type preferred by VC funds operating in Africa, a majority of VC funds ( $\mathrm{N}=66,55.00 \%$ ) adopt a general fund structure that allows them to invest in businesses that identify as early-stage through late-stage. $27.50 \%(\mathrm{~N}=33)$ of $\mathrm{VC}$ funds primarily fund early stage businesses while $17.50 \%(\mathrm{~N}=21)$ fund businesses seeking expansion and latestage funding (see Figure 2).
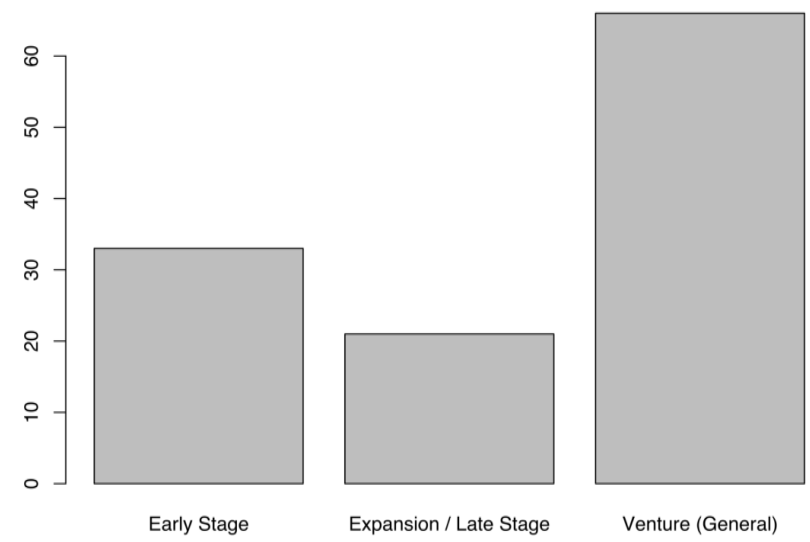

Figure 2: VC funds $(N)$ in Africa categorized by fund type

Regarding the geographical focus of VC funds operating in Africa, a majority of VC funds ( $\mathrm{N}=65,54.17 \%)$ have a national focus that limits the scope of their investing work to a single country. $16.67 \%(\mathrm{~N}=20)$ have a regional focus that allows them to consider 
investments within a particular region, i.e. East Africa. Finally, $29.17 \%(\mathrm{~N}=35)$ of the VC funds have a continental focus that allows them to consider investments across the whole continent. See Table 3 for more information.

Regarding the location of VC fund managers, nearly three quarters of the fund managers are located within the continent $(\mathrm{N}=89,74.17 \%)$, the rest are located in North America, Europe and the Middle East. Of those located in Africa, South Africa is the most popular location for fund managers $(\mathrm{N}=29,24.17 \%)$, followed by Morocco $(\mathrm{N}=11,9.17 \%)$ and Kenya ( $\mathrm{N}=9,7.50 \%)$. See Table 3 for more information.

\begin{tabular}{|c|c|c|c|c|c|c|}
\hline \multicolumn{7}{|c|}{ Fund Manager Location } \\
\hline & $N$ & $\%$ & $D B R$ & & $N$ & $\%$ \\
\hline Inside Africa: & \multicolumn{6}{|c|}{ Outside Africa: } \\
\hline South Africa & 29 & 24.17 & 82 & UK & 7 & 5.83 \\
\hline Morocco & 11 & 9.17 & 60 & USA & 6 & 5 \\
\hline Kenya & 9 & 7.5 & 61 & UAE & 4 & 3.33 \\
\hline Nigeria & 8 & 6.67 & 146 & France & 4 & 3.33 \\
\hline Tunisia & 7 & 5.83 & 80 & Netherlands & 4 & 3.33 \\
\hline Egypt & 6 & 5 & 120 & Australia & 2 & 1.67 \\
\hline Mauritius & 6 & 5 & 20 & Bahrain & 1 & 0.83 \\
\hline Ghana & 6 & 5 & 114 & Germany & 1 & 0.83 \\
\hline Botswana & 2 & 1.67 & 86 & Italy & 1 & 0.83 \\
\hline Zambia & 2 & 1.67 & 87 & Spain & 1 & 0.83 \\
\hline Sierra Leone & 2 & 1.67 & 163 & & & \\
\hline Ivory Coast & 1 & 0.83 & 122 & & & \\
\hline Total & 89 & 74.17 & & Total & 31 & 25.83 \\
\hline
\end{tabular}

Table 3. Fund manager locations. The table shows the number of funds by country location of fund managers. If country is inside Africa, the World Bank Doing Business Rank is also showed. ${ }^{*} D B R$ refers to World Bank 's Doing Business Rank.

Regarding the industry focus of VC funds operating in Africa, a majority of VC funds $(\mathrm{N}=79,65.83 \%)$ prefer a diversified industry focus that allows them to consider varied industries and have diversified portfolio. Beyond a diversified approach, specific industries that $\mathrm{VC}$ funds in Africa focus on include Internet, Technology and Telecom $(\mathrm{N}=24,20.00 \%)$, 
Energy and Cleantech $(\mathrm{N}=5,4.17 \%)$, Finance $(\mathrm{N}=4,3.33 \%)$ and Mining $(\mathrm{N}=3,2.50 \%)$. See Table 4 for more information.

Regarding the size of fundraising of VC funds operating in Africa, majority of the funds $(\mathrm{N}=67,55.83 \%)$ have raised under $\$ 25 \mathrm{~m}$, only $6.67 \%(\mathrm{~N}=8)$ have raised in excess of $\$ 100 \mathrm{~m}$. See Figure 3 for more information.

\section{Correlations, and associations between micro-level firm variables and VC fundraising}

\section{Correlations}

$\mathrm{VC}$ fundraising total was positively correlated with target size, $\mathrm{r}(120)=0.22, \mathrm{p}=0.018$. VC funds generally tended to raise funding in the region of their target size.

The number of domiciled fund managers was positively correlated with a country's Ease of Doing Business Rank r(12) $=0.25, \mathrm{p}=0.428$; however this correlation was not significant. Countries that ranked highly tended to have more fund managers.

Multiple linear regression model assessing the associations between total fundraising and microlevel firm variables

We used a multiple linear regression model to examine the associations between VC fundraising and the following micro-level firm variables: vintage year, fund type, target size, industry focus, location focus, and fund manager domicile. A significant regression equation emerged; $\mathrm{F}(21,98)=2.87, \mathrm{p}<0.001, \mathrm{R}^{2}=0.38($ see Table 5).

Association between industry focus and VC fundraising. Contrary to our predictions, we did not find a significant association between VC fundraising and industry focus; $\mathrm{F}(2798)$ $=0.778, \mathrm{p}=0.607$. 
Association between geographical variables and VC fundraising. As predicted, location focus was significantly associated with $\mathrm{VC}$ fundraising; $\mathrm{F}(2,98)=9.39, \mathrm{p}<0.001$. However, we did not find a significant association between VC fundraising and fund manager domicile $(\mathrm{F}(8,98)=1.73, \mathrm{p}=0.101)$ contrary to our predictions.

Association between other variables and VC fundraising. We had no prior hypotheses regarding the association between $\mathrm{VC}$ fundraising and fund type. We found a significant association between $\mathrm{VC}$ fundraising and fund type; $\mathrm{F}(2,98)=6.18, \mathrm{p}=0.003$.

We had no prior hypotheses regarding the association between VC fundraising and the vintage year of the $\mathrm{VC}$ fund. We found a significant association between $\mathrm{VC}$ fundraising and vintage year; $\mathrm{F}(1,98)=7.35, \mathrm{p}=0.008$.

We had no prior hypotheses regarding the association between VC fundraising and fundraising target. We did not find a significant association between VC fundraising and fundraising target; $F(1,98)=2.46, p=0.120$.

\section{Total VC Fundraising}

\begin{tabular}{lllc} 
Predictors & Estimates & \multicolumn{1}{c}{$C I$} & $p$ \\
\hline (Intercept) & -5024.77 & $-8449.75--1599.78$ & $\mathbf{0 . 0 0 5}$ \\
Vintage year & 2.53 & $0.82-4.24$ & $\mathbf{0 . 0 0 5}$ \\
Fund type & & & \\
$\quad$ Expansion/late stage & 33.04 & $8.68-57.40$ & $\mathbf{0 . 0 0 9}$ \\
$\quad$ Venture (general) & 17.59 & $-3.95-39.14$ & 0.113 \\
$\quad$ & 0.11 & $0.00-0.21$ & 0.051
\end{tabular}

Location focus

$\begin{array}{llll}\text { National } & -21.31 & -39.19--3.44 & \mathbf{0 . 0 2 1} \\ \text { Regional } & 8.26 & -13.99-30.50 & 0.469\end{array}$


Manager location

$\begin{array}{llll}\text { East Africa } & -41.87 & -136.76-53.01 & 0.389 \\ \text { Europe } & -39.93 & -131.69-51.82 & 0.396 \\ \text { Mauritius } & -16.80 & -112.12-78.52 & 0.730 \\ \text { Middle East } & -21.28 & -114.98-72.42 & 0.657 \\ \text { North Africa } & -56.99 & -149.59-35.61 & 0.231 \\ \text { North America } & -41.76 & -137.58-54.07 & 0.395 \\ \text { Southern Africa } & -39.90 & -129.31-49.50 & 0.384 \\ \text { West Africa } & -62.71 & -156.26-30.85 & 0.192\end{array}$

Industry focus

\begin{tabular}{llll} 
Diversified & 9.38 & $-46.25-65.02$ & 0.742 \\
Education & 81.91 & $-12.69-176.52$ & $\mathbf{0 . 0 9 3}$ \\
Energy \& cleantech & 12.50 & $-51.06-76.07$ & 0.701 \\
Finance & 15.92 & $-50.72-82.56$ & 0.641 \\
Healthcare \&pharma & 22.74 & $-53.47-98.95$ & 0.560 \\
Internet, technology \& telecom & 0.68 & $-58.42-59.79$ & 0.982 \\
Mining & -0.37 & $-94.52-93.79$ & 0.994 \\
\hline vations & 120 & & \\
djusted $\mathrm{R}^{2}$ & $0.381 / 0.248$ &
\end{tabular}

Table 5. Multiple linear regression assessing the associations between VC fundraising and various firm-wide variables.

\section{Discussion}

Because of the important role that small businesses play in many African economies, and since $\mathrm{VC}$ is now an established global investment for small businesses seeking growth capital, the present paper sought to expand the present understanding of VC in Africa. Specifically, we wanted to examine trends in the growth of VC activities in Africa with a 
special focus on the industry and geographical drivers of the same. We also wanted to examine the associations between VC fundraising and micro-level firm variables amongst VC funds with an investment focus in Africa between the year 2000 and 2018.

We found that at least $\$ 4.57 \mathrm{~b}$ dollars of VC has been raised for VC activities in Africa and that VC funds adopt certain approaches such as keeping diversified portfolios, investing in businesses across all stages of growth, and investing within domiciled countries. We also found significant associations between VC fundraising and VC fund type, location focus, and vintage year. We do not find similar associations between VC fundraising and industry focus, fund manager domicile or target size. These findings are discussed below.

\section{Five take-aways from two decades of VC activity in Africa}

Exploratory analysis of VC fundraising, and related VC activities afforded us an opportunity to identify interesting observations about the VC industry in Africa. These observations are particularly concern the nature of fundraising and investment approaches adopted by VC funds active in Africa since 2000. We discuss five of these observations:

\section{1. $\$ 4.57$ billion: a drop in the ocean or a splash in the pool?}

$\$ 4.57 b$ was raised by African-focused VC funds between 2000 and 2018, but what does $\$ 4.57 b$ signify?

On one hand, $\$ 4.57 \mathrm{~b}$ appears to be a drop in the ocean. As seen in Figure 4, when we compare VC fundraising in Africa and the United States, the premiere VC market in the world, it appears that the VC industry in Africa is still in its infancy and yet to take off. VC firms in the US have invested over $\$ 850$ in the same period of time and have invested more 
than $\$ 15$ b each year since 20003. European VC funds committed $\$ 4.86$ b in 2016 alone (Invest Europe, 2017), and VC fundraising in Latin America was calculated to have exceeded \$5b between 2010 and 2018 (Crunchbase, 2018). Given these trends around the world, it appears that VC activities in Africa are lagging behind that in other regions in the world. Cross-regional analysis of $\mathrm{VC}$ activities is needed to ascertain the nature and magnitude of these gap.

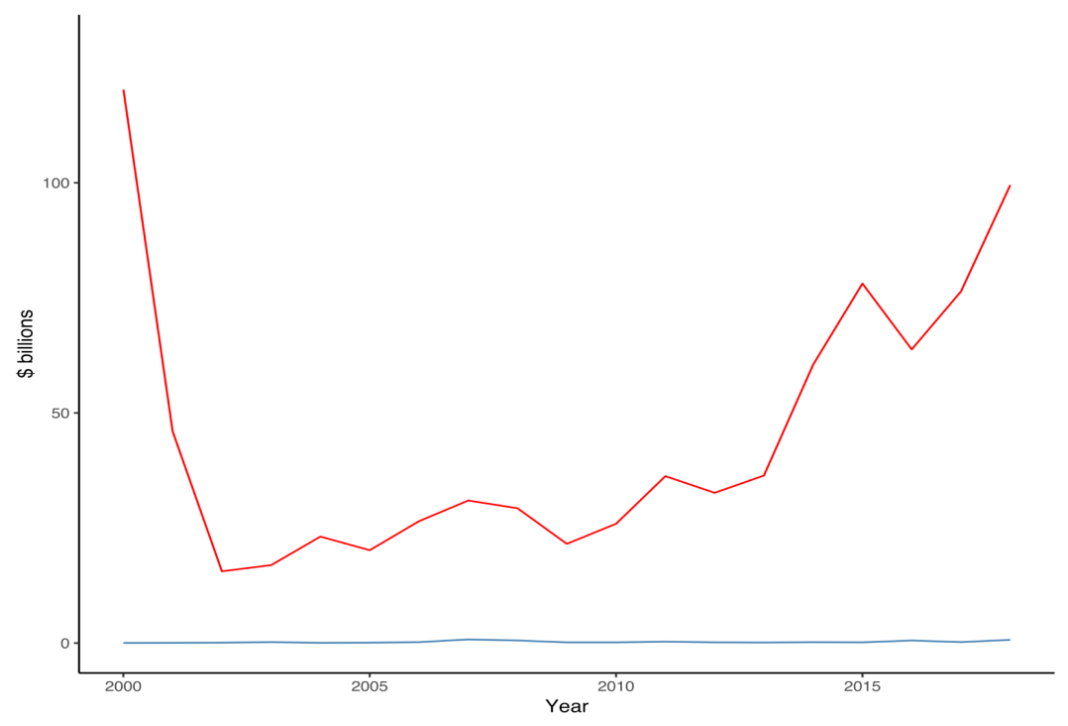

Figure 4. VC fundraising in Africa compared to VC investing in the US. When compared to the most developed VC market, it appears that the African VC industry is yet to take off.

On the other hand, $\$ 4.57 \mathrm{~b}$ is progress. When we consider that only $\$ 29 \mathrm{~m}$ was raised for VC activities in Africa in 2000, the over 2,300\% growth in VC fundraising is indeed remarkable progress. At the turn of the millennium, many considered Africa closed for business. Indeed, The Economist ran the now infamous cover 'the hopeless continent', that portrayed Africa as a continent unable to build the institutions it needed for economic

\footnotetext{
${ }^{3}$ Numbers based on calculations by author from various data sources such as Statista and
} CrunchBase. 
progress (The Economist, May 11, 2000). But true to the African proverb, 'dawn break however long the night', in the past two decades many African economies have enjoyed stability, economic growth and established business friendly institutions that have opened their economies to outside investments. The impact of this increased $\mathrm{VC}$ activities promises to be profound for many small businesses. $\$ 4.5 \mathrm{~b}$ is a splash in the pond.VC fundraising will benefit immensely from this encouraging development. Because of this rise in VC money, many opportunities will arise for small businesses in Africa. $\$ 4.57 \mathrm{~b}$ is the first splash in the pond.

\section{To specialize or not? That is the question}

It appears that VC funds in Africa favour a generalized approach to fund type and diversification. We found that most of the funds preferred to invest across multiple industries and in businesses at all levels of growth. This approach makes sense as diversification of portfolios, and investing in companies at different stages allow funds to minimize both unsystematic risk and investment-specific risk (Norton \& Tenenbaum, 1993). While diversification is the favoured approach, specialization also offers advantages. Specialized funds focus on particular industries and type of businesses. They develop efficiency in information gathering and build strong industry networks that also allow them to minimize unsystematic risk and investment-specific risk (Norton \& Tenenbaum, 1993). Furthermore, a previous study has made the case for VC specialization by showing strong associations between specialization and investee success (Gompers et al., 2009). Thus, while VC firms in Africa prefer and can be served by a diversified approach, they should also consider specialization as some industries can benefit from such an approach. 
Some VC funds in Africa have considered specialization and one the Internet, Technology and Telecom industry has emerged as a favored specialization for many funds. This observation is an accurate reflection of the ways in which this industry has disrupted life in Africa over the past two decades. From the rapid growth of mobile phones and internet, though the rise of mobile money, to the new 'Silicon Savannah' phenomenon of tech startups in various hubs in the continent; it appears that the Internet, Technology and Telecom industry has driven demand for VC funding in Africa. VC funds are encouraged to look at similar disruptive industries and consider specialization.

\section{Patriot funds: Single country VC players}

Many VC funds in Africa focus their investments within their domiciled nations. This is because of an increase in nationally focused funds that often arise as specialized investment vehicles of public-private partnerships or similar enterprises. These funds appear to be particularly popular in Northern and Southern African. We discuss two of these funds briefly. The first is the Maroc Numeric Fund (MNF), a public-private investment fund dedicated to financing Moroccan technology startups exclusively. MNF invests between $\$ 0.1 \mathrm{~m}$ to $\$ 0.4 \mathrm{~m}$ in early stage businesses, and $\$ 0.4 \mathrm{~m}$ to $\$ 1 \mathrm{~m}$ in growth stage businesses. The second is Kukula Capital, a private investment fund that resulted from collaboration between Danish organizations and Zambian investors and invests between $\$ 0.1 \mathrm{~m}$ to $\$ 0.5 \mathrm{~m}$ in Zambian small businesses from diverse industries. Both funds are good models of innovative fundraising by VC funds for within-country focused funds. Similar models have been used successfully and improved VC fundraising in China and Israel (Ahlstrom, Bruton, \& Yeh, 2007; Mayer, Schoors, \& Yafeh, 2005). 


\section{Rumble in the jungle: Fund managers are close to the action}

It is encouraging that many $\mathrm{VC}$ fund managers are domiciled within the continent. Geography is important in the VC industry (Elango et al., 1995). By locating themselves in the continent, $\mathrm{VC}$ fund managers can develop an intimate understanding of the businesses that they invest in.

\section{Does size matter? Small checks and big dreams}

As seen in Figure 3, VC funds in Africa raise small checks, mostly under $\$ 25 \mathrm{~m}$. Very few raise more than $\$ 100 \mathrm{~m}$. This undoubtedly presents a constraint on the activities of many VC firms. They are limited in the size and scope of their investments. However, given the dearth of alternative financing options, even such small-pocketed VC funds can be of profound impact to businesses in the continent and should be encouraged.

\section{Micro-level drivers of VC fundraising in Africa}

Using a multiple linear regression model, we also examined the associations between. microlevel firm variables and VC fundraising (see Table 4). We found that location focus, fund type, and vintage year were significantly associated with VC fundraising. We did not find similar associations between VC fundraising and industry focus, fund manager domicile, and fundraising target size. While further analyses are required to replicate these findings, fund managers and fund investors are urged to consider these findings. Should need be, they can determine or update their fundraising strategies to take these factors into consideration.

\section{Study limitations and future directions}

The first limitation of the present study is our data sources. Data on VC firms, most of which are privately held, are rare and tiresome to develop. As such, research often relies on third 
party data sources. In the present study, we relied on Preqin's private equity database. Preqin sources its data on VC firms from a variety of sources. First, they gather data from pension funds public filings, and other available public data. Second, they solicit voluntary filings from VC partners and managers. Even though Preqin's data are transparent and verifiable (they name funds and partners), they are susceptible to missing firms that do not have public filings, and their data might not be up to date because of the slow process of voluntary data reporting (Kaplan \& Lerner, 2016). As such, our study carries these biases into its analysis. It is important that future research with alternative and complimentary databases replicate these findings.

A second limitation is that the variables we examined when considering the associations between VC fundraising and micro-level firm variables are confounded to some extent. We took steps to address the relations among these variables, but there is no way to completely account for this dependence.

Our study suggests several avenues for future research. First, further research should consider other micro-level firm variables and how they influence VC activity in Africa. Second, macro factors and how they influence VC activities should be investigated. Such a consideration was beyond the scope of the present paper whose objectives were of an exploratory and micro analysis nature. Third, research on how VC activity effect on business and business owners can be of utmost importance to small businesses in Africa that seek venture capital funding to scale and grow.

\section{References}

Abor, J., \& Quartey, P. (2010). Issues in SME development in Ghana and South Africa. International Research Journal of Finance and Economics, (39), 218-228. 
Adongo, J. (2011). Determinants of venture capital in Africa: Cross section evidence (No. 237). Nairobi, Kenya: African Economic Research Consortium.

Ahlstrom, D., Bruton, G. D., \& Yeh, K. S. (2007). Venture capital in China: Past, present, and future. Asia Pacific Journal of Management, 24(3), 247-268. https://doi.org/10.1007/s10490$006-9032-1$

Ayyagari, M., Demirgüç-Kunt, A., \& Beck, T. (2003). Small and medium enterprises across the globe: A new database. https://doi.org/10.1596/1813-9450-3127

Baumann, T. (2004). Pro-poor microcredit in South Africa: cost-efficiency and productivity of South African pro-poor microfinance institutions. Development Southern Africa, 21(5), 785798. https://doi.org/10.1080/0376835042000325705

Bertoni, F., Colombo, M. G., \& Quas, A. (2015). The patterns of venture capital investment in Europe. Small Business Economics, 45(3), 543-560. https://doi.org/10.1007/s11187-015-96620

Black, B. S., \& Gilson, R. J. (1998). Venture capital and the structure of capital markets: banks versus stock markets. Journal of Financial Economics, 47(3), 243-277. https://doi.org/10.1016/S0304-405X(97)00045-7

Bruton, G., Ahlstrom, D., \& Yeh, K. S. (2004). Understanding venture capital in East Asia: the impact of institutions on the industry today and tomorrow. Journal of World Business, 39(1), 72-88. https://doi.org/10.1016/j.jwb.2003.08.002

Buuren, S. van, \& Groothuis-Oudshoorn, K. (2011). mice: Multivariate imputation by chained equations in R. Journal of Statistical Software, 45(1), 1-67. https://doi.org/10.18637/jss.v045.i03

Chen, H., Gompers, P., Kovner, A., \& Lerner, J. (2010). Buy local? The geography of venture capital. Journal of Urban Economics, 67(1), 90-102. https://doi.org/10.1016/j.jue.2009.09.013 
Crunchbase. (2018, December 10). 2018: The year VC in Latin America began to close the gap. Retrieved April 17, 2019, from Crunchbase News website: https://news.crunchbase.com/news/2018-the-year-vc-in-latin-america-began-to-close-the-gap

Cumming, D. J. (2005). Agency costs, institutions, learning, and taxation in venture capital contracting. Journal of Business Venturing, 20(5), 573-622. https://doi.org/10.1016/j.jbusvent.2003.07.001

de Haan, L., \& Lakwo, A. (2010). Rethinking the impact of microfinance in Africa: 'Business change' or social emancipation. The European Journal of Development Research, 22(4), 529545. https://doi.org/10.1057/ejdr.2010.32

Elango, B., Fried, V. H., Hisrich, R. D., \& Polonchek, A. (1995). How venture capital firms differ. Journal of Business Venturing, 10(2), 157-179. https://doi.org/10.1016/0883-9026(94)00019-Q

Fatoki, O., \& Odeyemi, A. (2010). Which New small and medium enterprises in South Africa have access to bank credit? International Journal of Business and Management, 5(10), p128. https://doi.org/10.5539/ijbm.v5n10p128

Gbandi, E. C., \& Amissah, G. (2014). Financing options for small and medium enterprises (SMEs) in Nigeria. European Scientific Journal, 10(1).

Gompers, P., Kovner, A., \& Lerner, J. (2009). Specialization and success: Evidence from venture capital. Journal of Economics \& Management Strategy, 18(3), 817-844. https://doi.org/10.1111/j.1530-9134.2009.00230.x

Gompers, P., \& Lerner, J. (2001). The Venture capital revolution. The Journal of Economic Perspectives, 15(2), 145-168.

Guler, I., \& Guillén, M. F. (2010). Institutions and the internationalization of US venture capital firms. Journal of International Business Studies, 41(2), 185-205. https://doi.org/10.1057/jibs.2009.35

Harrison, R. T., \& Mason, C. M. (2019). Venture capital 20 years on: reflections on the evolution of a field. Venture Capital, 21(1), 1-34. https://doi.org/10.1080/13691066.2019.1562627 
The Economist. (2000, May 11). Hopeless Africa. Retrieved from https://www.economist.com/leaders/2000/05/11/hopeless-africa

Invest Europe. (2017). The acceleration point: Why now is the time for European venture capital. Brussels, Belgium: Invest Europe.

Jefferis, K., \& Smith, G. (2005). The changing efficiency of African stock markets. South African Journal of Economics, 73(1), 54-67. https://doi.org/10.1111/j.1813-6982.2005.00004.x

Kaplan, S., \& Lerner, J. (2016). Venture capital data: Opportunities and challenges (No. w22500; p. w22500). https://doi.org/10.3386/w22500

Kauffmann, C. (2005). Financing SMEs in Africa (No. 7). OECD Development Centre.

Kenny, C. J., \& Moss, T. J. (1998). Stock markets in Africa: Emerging lions or white elephants? World Development, 26(5), 829-843. https://doi.org/10.1016/S0305-750X(98)00019-9

Ksoll, C., Lilleør, H. B., Lønborg, J. H., \& Rasmussen, O. D. (2016). Impact of village savings and loan associations: Evidence from a cluster randomized trial. Journal of Development Economics, 120, 70-85. https://doi.org/10.1016/j.jdeveco.2015.12.003

Lafourcade, A-L., Isern, J., Mwangi, P., \& Brown, M. (2005). Overview of the Outreach and Financial Performance of Microfinance Institutions in Africa. Microfinance Information eXchange (MIX).

Lapenu, C., \& Zeller, M. (2001). Distribution, growth and performance of microfinance institutions In Africa, Asia and Latin America. Retrieved from http://ageconsearch.umn.edu/record/16446/files/fc010114.pdf

Lerner, J., \& Tåg, J. (2013). Institutions and venture capital. Industrial and Corporate Change, 22(1), 153-182. https://doi.org/10.1093/icc/dts050

Mayer, C., Schoors, K., \& Yafeh, Y. (2005). Sources of funds and investment activities of venture capital funds: evidence from Germany, Israel, Japan and the United Kingdom. Journal of Corporate Finance, 11(3), 586-608. https://doi.org/10.1016/j.jcorpfin.2004.02.003 
Memba, S. F., Gakure, W. R., \& Karanja, K. (2012). Venture capital (VC): its impact on growth of small and medium enterprises in Kenya. International Journal of Business and Social Science, $3(6), 32-38$.

Miled, K. B. H., \& Rejeb, J.-E. B. (2015). Microfinance and poverty reduction: A review and synthesis of empirical Evidence. Procedia - Social and Behavioral Sciences, 195, 705-712. https://doi.org/10.1016/j.sbspro.2015.06.339

Mosley, P., \& Rock, J. (2004). Microfinance, labour markets and poverty in Africa: a study of six institutions. Journal of International Development, 16(3), 467-500.

https://doi.org/10.1002/jid.1090

Nahata, R., Hazarika, S., \& Tandon, K. (2014). Success in global venture capital investing: Do institutional and cultural differences matter? Journal of Financial and Quantitative Analysis, 49(4), 1039-1070. https://doi.org/10.1017/S0022109014000568

Norton, E., \& Tenenbaum, B. H. (1993). Specialization versus diversification as a venture capital investment strategy. Journal of Business Venturing, 8(5), 431-442. https://doi.org/10.1016/0883-9026(93)90023-X

Phillips, C., \& Bhatia-Panthaki, S. (2007). Enterprise development in Zambia: reflections on the missing middle. Journal of International Development, 19(6), 793-804. https://doi.org/10.1002/jid.1402

Rowley, J. D. (2019, January 7). Q4 2018 closes out a record year for the global vc market. Retrieved April 15, 2019, from Crunchbase News website: https://news.crunchbase.com/news/q4-2018-closes-out-a-record-year-for-the-global-vc-market Rwegasira, K. (2000). Corporate governance in emerging capital markets: Whither Africa? Corporate Governance: An International Review, 8(3), 258-267. https://doi.org/10.1111/14678683.00203

Sapienza, H. J. (1992). When do venture capitalists add value? Journal of Business Venturing, 7(1), 9-27. https://doi.org/10.1016/0883-9026(92)90032-M 
Weng, L., Boedhihartono, A. K., Dirks, P. H. G. M., Dixon, J., Lubis, M. I., \& Sayer, J. A. (2013). Mineral industries, growth corridors and agricultural development in Africa. Global Food Security, 2(3), 195-202. https://doi.org/10.1016/j.gfs.2013.07.003

Woller, G. (2002). From market failure to marketing failure: market orientation as the key to deep outreach in microfinance. Journal of International Development, 14(3), 305-324.

https://doi.org/10.1002/jid.883 


\section{Tables and Figures}

Table 1. Study Variables.

\begin{tabular}{|c|c|c|c|}
\hline Variable & Notes & Variable & Notes \\
\hline $\begin{array}{l}C C \\
\text { fundraising }\end{array}$ & $\begin{array}{l}\text { Refers to the total amount of funding raised by VC funds in } \\
\text { a particular time period. We used the final fund size } \\
\text { variable from Preqin to operationalize this. }\end{array}$ & $\begin{array}{l}\text { Target } \\
\text { size }\end{array}$ & $\begin{array}{l}\text { This refers to the fundraising target set by } \mathrm{VC} \text { fund } \\
\text { before fundraising. We used the target size variable } \\
\text { from Preqin to operationalize this. }\end{array}$ \\
\hline $\begin{array}{l}\text { Vintage } \\
\text { year }\end{array}$ & $\begin{array}{l}\text { Refers to the year in which the first influx of investment } \\
\text { capital is delivered to a VC fund. This marks when capital } \\
\text { is contributed by VC fund investors. We used the vintage } \\
\text { year variable from Preqin to operationalize this. }\end{array}$ & $\begin{array}{l}\text { Industry } \\
\text { focus }\end{array}$ & $\begin{array}{l}\text { This refers to the industry that the VC focuses on } \\
\text { when considering investments. We used the industry } \\
\text { focus variable from Preqin to operationalize this. If a } \\
\text { VC wasn't classified by Preqin as 'diversified' but } \\
\text { had more than three distinct industries listed, we } \\
\text { classified it as 'diversified'. }\end{array}$ \\
\hline Fund type & $\begin{array}{l}\text { This refers to the type of stage that VC fund invests in. } \\
\text { From the Preqin data it can be classified as either early } \\
\text { stage, expansion/late stage, or venture (general). We used } \\
\text { the fund type variable from Preqin to operationalize this. }\end{array}$ & $\begin{array}{l}\text { Fund } \\
\text { location } \\
\text { focus }\end{array}$ & $\begin{array}{l}\text { This refers to whether the } \mathrm{VC} \text { fund focuses on making } \\
\text { national, regional or continental investments. To code } \\
\text { this, we used the location focus variable from Preqin } \\
\text { to operationalize this. If the location focus was a } \\
\text { single county, we categorized the variable as }\end{array}$ \\
\hline $\begin{array}{l}\text { Fund } \\
\text { manager } \\
\text { domicile }\end{array}$ & $\begin{array}{l}\text { This refers to the location of the fund manager. Preqin } \\
\text { provides this data as fund manager country. We used this } \\
\text { value to code this variable as a region. For instance, if a } \\
\text { fund manager had Kenya as the fund manager country, we } \\
\text { coded this as 'East Africa'. }\end{array}$ & & $\begin{array}{l}\text { 'national' (i.e. Kenya was classified as 'national'), if } \\
\text { it was countries from the same region, we categorized } \\
\text { it as regional (i.e. Kenya, Tanzania, Uganda was } \\
\text { classified as 'regional'). If it had countries from more } \\
\text { than one region, we categorized it as continental, (i.e. } \\
\text { Kenya, Tanzania, Uganda, Ghana, Nigeria, South } \\
\text { Africa was classified as 'continental'). }\end{array}$ \\
\hline
\end{tabular}


Table 2. Time series data showing VC fundraising in Africa from 2000 to 2018. Other relevant information such as numbers of funds, number of firms (fund managers), and average fund size (average of total fundraising) are also highlighted.

\begin{tabular}{cccccc}
\hline $\begin{array}{c}\text { Vintage } \\
\text { Year }\end{array}$ & $\begin{array}{c}\text { Total } \\
\text { Fund Size }\end{array}$ & $\begin{array}{c}\text { Number of } \\
\text { Funds (N) }\end{array}$ & $\begin{array}{c}\text { Number } \\
\text { of Firms } \\
(\mathrm{N})\end{array}$ & $\begin{array}{c}\text { Average } \\
\text { Fund Size }\end{array}$ & $\begin{array}{c}\text { Fund Size } \\
\text { SD }\end{array}$ \\
\hline 2000 & 29.1 & 2 & 2 & 14.55 & 12.23 \\
2001 & 45.5 & 2 & 2 & 22.75 & 15.32 \\
2002 & 88.88 & 4 & 4 & 22.22 & 23.77 \\
2003 & 207.87 & 7 & 5 & 29.7 & 17.2 \\
2004 & 51.61 & 3 & 3 & 17.2 & 15.14 \\
2005 & 93.49 & 4 & 4 & 23.37 & 12.51 \\
2006 & 195.28 & 7 & 7 & 27.9 & 16.86 \\
2007 & 785.8 & 16 & 15 & 49.11 & 37.85 \\
2008 & 572.22 & 8 & 8 & 71.53 & 51.72 \\
2009 & 147.13 & 6 & 6 & 24.52 & 28.57 \\
2010 & 154.83 & 8 & 8 & 19.35 & 16.12 \\
2011 & 309.83 & 8 & 8 & 38.73 & 40.76 \\
2012 & 159.21 & 7 & 7 & 22.74 & 24.92 \\
2013 & 124.38 & 6 & 6 & 20.73 & 30.06 \\
2014 & 185.8 & 4 & 4 & 46.45 & 41.52 \\
2015 & 164.29 & 6 & 6 & 27.38 & 23.41 \\
2016 & 563.79 & 8 & 8 & 70.47 & 84.6 \\
2017 & 205 & 3 & 3 & 68.33 & 54.85 \\
2018 & 704.86 & 11 & 10 & 64.08 & 49.84 \\
\hline \hline
\end{tabular}


Table 3. Fund manager locations. The table shows the number of funds by country location of fund managers. If country is inside Africa, the World Bank Doing Business Rank is also showed.

\begin{tabular}{|c|c|c|c|c|c|c|}
\hline \multicolumn{7}{|c|}{ "Fund Manager Location } \\
\hline & $N$ & $\%$ & $D B R$ & & $N$ & $\%$ \\
\hline Inside Africa: & \multicolumn{6}{|c|}{ Outside Africa: } \\
\hline South Africa & 29 & 24.17 & 82 & UK & 7 & 5.83 \\
\hline Morocco & 11 & 9.17 & 60 & USA & 6 & 5 \\
\hline Kenya & 9 & 7.5 & 61 & UAE & 4 & 3.33 \\
\hline Nigeria & 8 & 6.67 & 146 & France & 4 & 3.33 \\
\hline Tunisia & 7 & 5.83 & 80 & Netherlands & 4 & 3.33 \\
\hline Egypt & 6 & 5 & 120 & Australia & 2 & 1.67 \\
\hline Mauritius & 6 & 5 & 20 & Bahrain & 1 & 0.83 \\
\hline Ghana & 6 & 5 & 114 & Germany & 1 & 0.83 \\
\hline Botswana & 2 & 1.67 & 86 & Italy & 1 & 0.83 \\
\hline Zambia & 2 & 1.67 & 87 & Spain & 1 & 0.83 \\
\hline Sierra Leone & 2 & 1.67 & 163 & & & \\
\hline Ivory Coast & 1 & 0.83 & 122 & & & \\
\hline Total & 89 & 74.17 & & otal & 31 & 25.83 \\
\hline
\end{tabular}

*DBR refers to World Bank 's Doing Business Rank.

Table 4: Fund variables. The table shows the distribution of VC funds by industry focus, geographical focus and fund size.

\begin{tabular}{|c|c|c|c|c|c|}
\hline \multicolumn{3}{|l|}{ Fund Industry Focus } & \multicolumn{3}{|c|}{ Fund Size Categories } \\
\hline & $N$ & $\%$ & & $N$ & $\%$ \\
\hline Diversified & 79 & 65.83 & Less than $\$ 10 \mathrm{~m}$ & 31 & 25.83 \\
\hline Internet, Technology \& Telecom & 24 & 20 & Between $\$ 11-25 \mathrm{~m}$ & 36 & 30 \\
\hline Energy \& Cleantech & 5 & 4.17 & Between $\$ 26-50 \mathrm{~m}$ & 19 & 15.83 \\
\hline Finance & 4 & 3.33 & Between $\$ 50-75$, & 13 & 10.83 \\
\hline Mining & 3 & 2.5 & Between \$76-100, & 13 & 10.83 \\
\hline Healthcare \&Pharma & 2 & 1.67 & Greater than $\$ 100 \mathrm{~m}$ & 8 & 6.67 \\
\hline Agriculture & 2 & 1.67 & & & \\
\hline Education & 1 & 0.83 & & & \\
\hline \multicolumn{3}{|c|}{ Fund Geographical Focus } & & & \\
\hline & $\mathrm{N}$ & $\%$ & & & \\
\hline Continental & 35 & 29.17 & & & \\
\hline Regional & 20 & 16.67 & & & \\
\hline National & 65 & 54.17 & & & \\
\hline
\end{tabular}


Table 5. Multiple linear regression assessing the associations between VC fundraising and various firm-wide variables.

\begin{tabular}{|c|c|c|c|}
\hline \multirow[b]{2}{*}{ Predictors } & \multicolumn{3}{|c|}{ Total VC Fundraising } \\
\hline & Estimates & $C I$ & $p$ \\
\hline (Intercept) & -5024.77 & $-8449.75--1599.78$ & 0.005 \\
\hline Vintage year & 2.53 & $0.82-4.24$ & 0.005 \\
\hline \multicolumn{4}{|l|}{ Fund type } \\
\hline Expansion/late stage & 33.04 & $8.68-57.40$ & 0.009 \\
\hline Venture (general) & 17.59 & $-3.95-39.14$ & 0.113 \\
\hline Target size & 0.11 & $0.00-0.21$ & 0.051 \\
\hline \multicolumn{4}{|l|}{ Location focus } \\
\hline National & -21.31 & $-39.19--3.44$ & 0.021 \\
\hline Regional & 8.26 & $-13.99-30.50$ & 0.469 \\
\hline \multicolumn{4}{|l|}{ Manager location } \\
\hline East Africa & -41.87 & $-136.76-53.01$ & 0.389 \\
\hline Europe & -39.93 & $-131.69-51.82$ & 0.396 \\
\hline Mauritius & -16.80 & $-112.12-78.52$ & 0.730 \\
\hline Middle East & -21.28 & $-114.98-72.42$ & 0.657 \\
\hline North Africa & -56.99 & $-149.59-35.61$ & 0.231 \\
\hline North America & -41.76 & $-137.58-54.07$ & 0.395 \\
\hline Southern Africa & -39.90 & $-129.31-49.50$ & 0.384 \\
\hline West Africa & -62.71 & $-156.26-30.85$ & 0.192 \\
\hline
\end{tabular}

Industry focus

Diversified

Education

Energy \& cleantech
9.38

$-46.25-65.02$

0.742

81.91

$-12.69-176.52$

0.093

$12.50 \quad-51.06-76.07$

0.701 


\begin{tabular}{llll} 
Finance & 15.92 & $-50.72-82.56$ & 0.641 \\
Healthcare \&pharma & 22.74 & $-53.47-98.95$ & 0.560 \\
Internet, technology \& telecom & 0.68 & $-58.42-59.79$ & 0.982 \\
Mining & -0.37 & $-94.52-93.79$ & 0.994 \\
\hline Observations & 120 & & \\
$\mathrm{R}^{2} /$ adjusted $\mathrm{R}^{2}$ & $0.381 / 0.248$ & \\
\hline \hline
\end{tabular}

Figure 1. VC fundraising (in \$ millions) in Africa between 2000 and 2018.

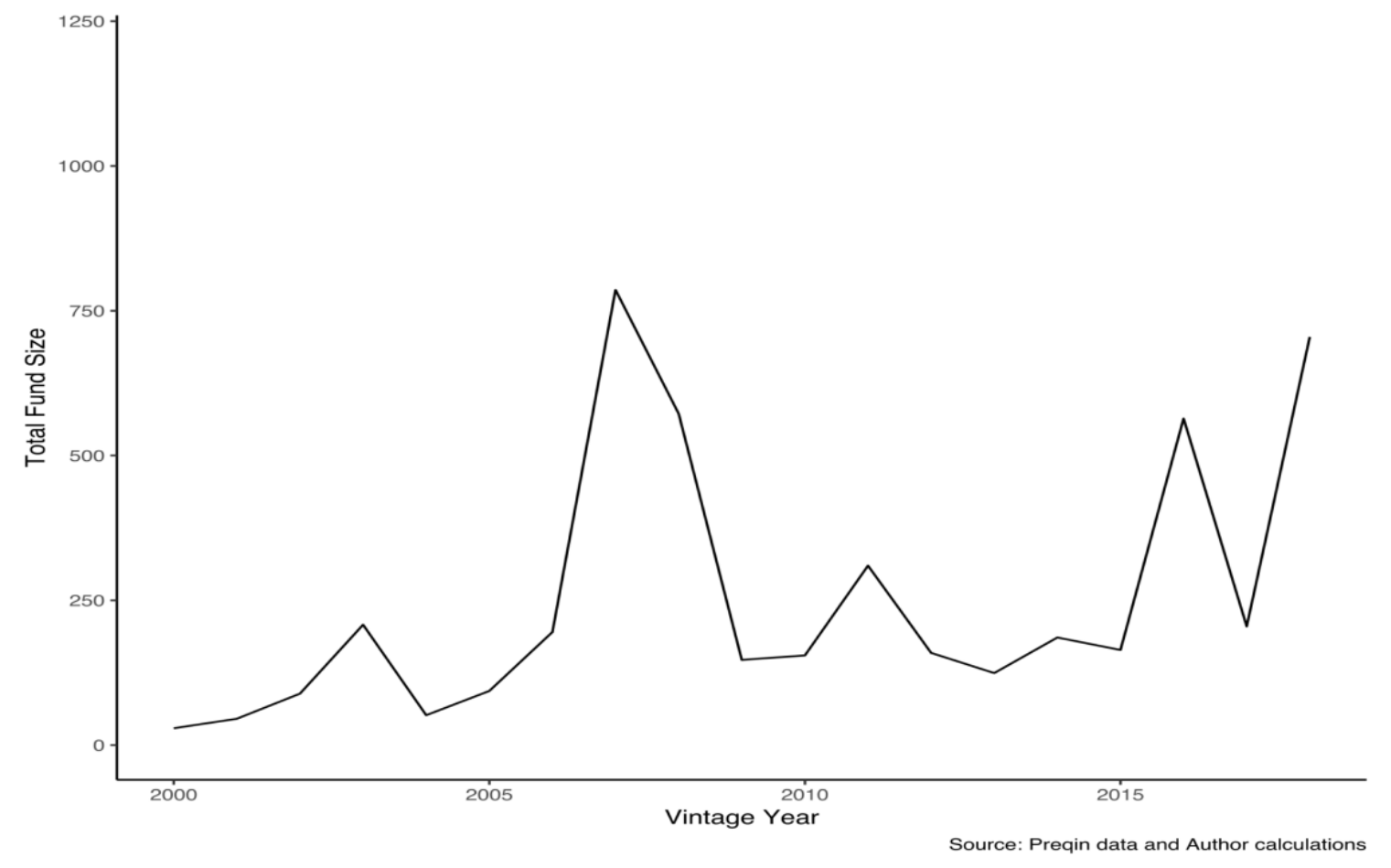


Figure 2. VC funds (N) in Africa categorized by fund type


Figure 3. VC funds (N) categorized by the size of their total fundraising.
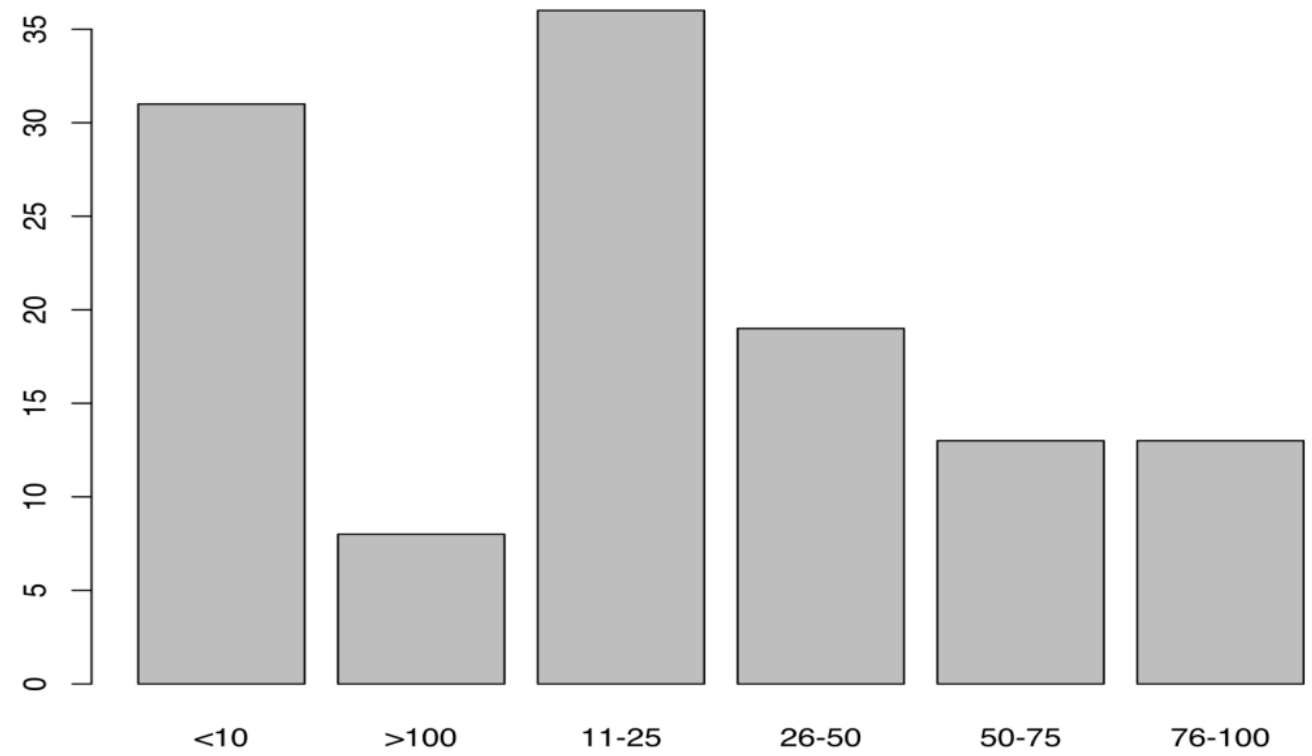

26-50

50-75

76-100

Figure 4. VC fundraising in Africa compared to VC investing in the US. When compared to the most developed VC market, it appears that the African VC industry is yet to take off. 


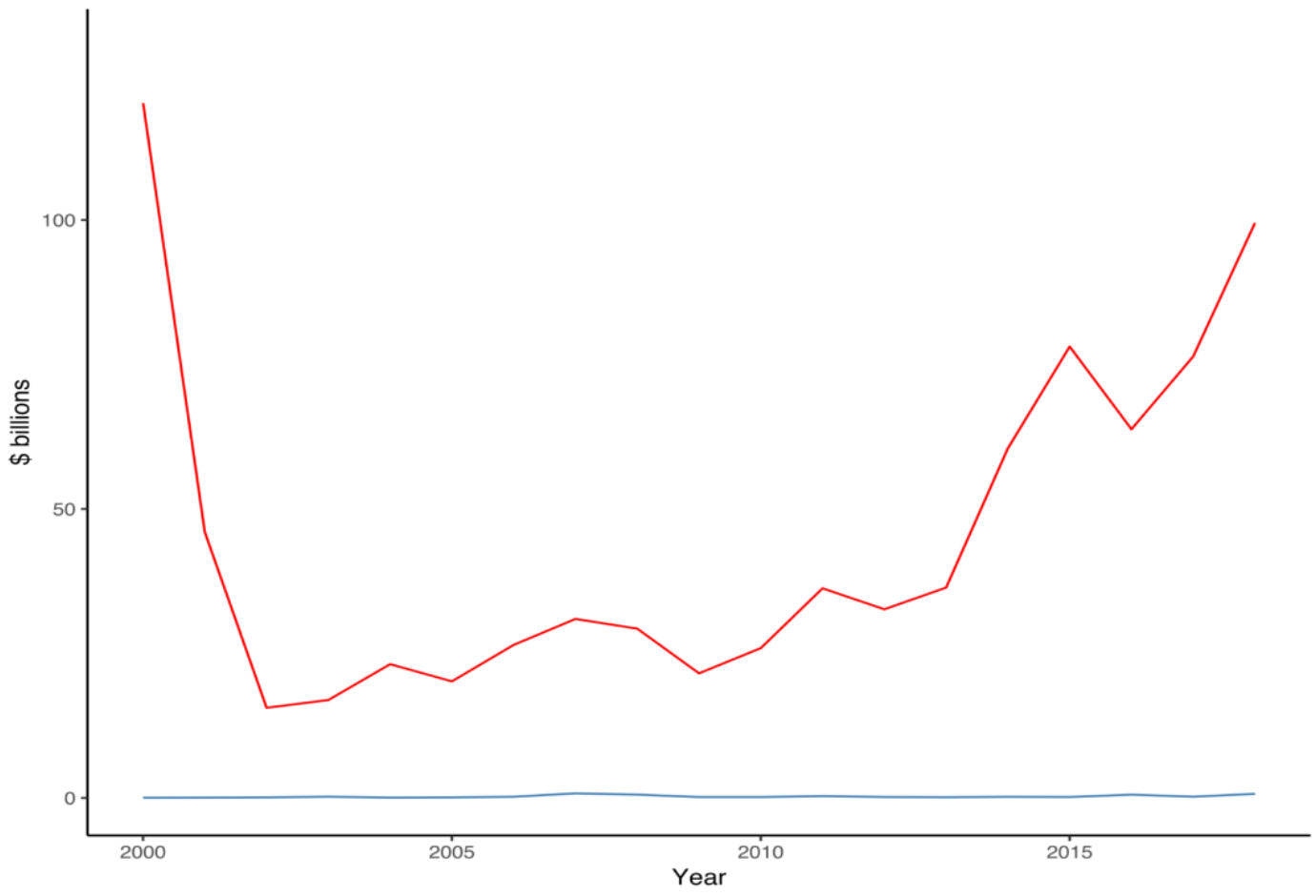

Numbers calculated by author using data from various online databases that track VC investing, including Statista and CrunchBase. 